\title{
THE IMPACT OF ONLINE LEARNING DURING THE COVID-19 PANDEMIC ON PHYSICAL EDUCATION TEACHERS
}

\author{
Taufik Rahman ${ }^{1}$, Dyas Andry Prasetyo ${ }^{2}$, Hendra Mashuri ${ }^{3}$ \\ STKIP PGRI Sumenep ${ }^{1,2}$, Universitas Pendidikan Ganesha ${ }^{3}$ \\ opick_conk@stkippgrisumenep.ac.id, dyasandry@stkippgrisumenep.ac.id, \\ hendra.mashuri@undiksha.ac.id
}

\begin{abstract}
Physical education is an integral part of the educational process that demands to learn through physical activity. The learning process through physical activity requires intense supervision from physical education teachers. However, the Covid-19 pandemic has forced physical education learning to be carried out from the homes of each student, as a result there is no strict supervision from physical education teachers. This study to determine the impact of learning physical education (PE) during the covid-19 pandemic on PE teacher in Sumenep Regency. The type of research is survey. The instrument used online learning process questionnaire. The object of the research is PE teacher in elementary and high schools in Sumenep Regency. The analysis of data used qualitative descriptive analysis. The results of this study is it can be concluded that the impact of learning during the covid-19 pandemic is the PE teachers are required to improve the digital literacy because the delivery of information in form of learning material is online delivered. PE teachers have to strategies and innovation to overcome the obstacles faced during the implementation of online learning. PE teachers hato to choose the right media to make more interesting learning. During the covid-19 pandemic, PE teachers were forced to be more open to digital literacy and to be more creative in learning and to have high innovative abilities. Great expectation to be able to find the solution of social, economic, and technical teaching of physical education for the learning process can be accomplished in accordance with the educational goals of national education.
\end{abstract}

Keywords: Physical Education, PE Teachers, PE Learning, Covid-19 Pandemic

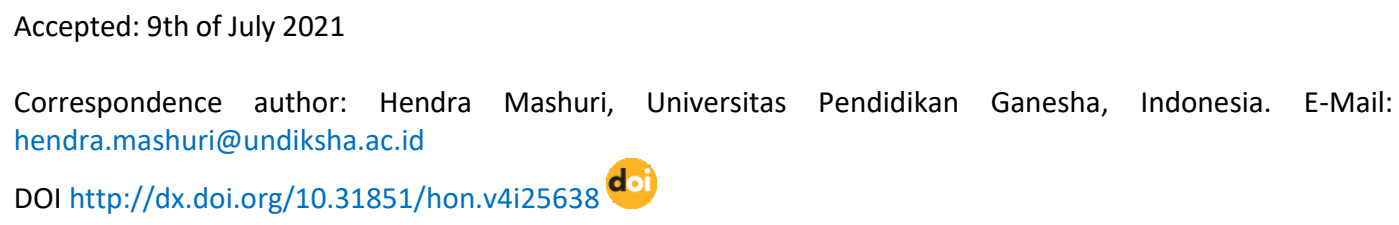

\section{(7) (2)}

Jurnal Halaman Olahraga Nusantara licensed under a Creative Commons Attribution-ShareAlike 4.0 International License.

\section{INTRODUCTION}

In early 2020, the world is shocked by the appearance of corona virus (COVID-19), which can kill infected. Corona virus spread very simple and fast is through touch and or dissemination through breathing. While the pandemic has 
influenced all human activities and limit them at home (Okilanda et al., 2021)

This makes people very careful about interacting with other people.

The Government of the Republic of Indonesia is responding to the corona virus by issuing a policy so that people do not gather and carry out activities outside the home. Including limiting the teaching and learning activities in schools and other educational institutions, including universities (Mashuri, 2020). Restrictions forcing educational activities educational actors (teachers and students) to learn and learning from home in virtual (online). Virtual learning is a modest effort that appeared to be accomplished educational interaction, but can not be a solution in achieving educational goals.

Based on the research results Jatira \& Neviyarni (2021) show that online learning (virtual) during pandemic covid-19 cause learners to experience stress and habituation of online learning (online) causes students to become bored and lazy. Several of the first reported studies examining the impact of the COVID-19 pandemic on children's physical activities levels present interesting findings. Short-term studies in the United States and China documented decreased levels of PA during stay-at-home orders and school closures (Dunton et al., 2020; Xiang et al., 2020).

In mid-2020, the Government of the Republic of Indonesia through the Ministry of Education and Culture of the new policy during the New Normal. New normal is a form of new habits in the life of Indonesian society, including new habits in educational practice. A small portion was allowed to carry out learning classes directly to uphold the health protocol, but the impact on the increase of people with covid 19 so that the practice of education returned to learn online. This affects education actors are forced to make optimum use of information technology media such as class google, google meet, and zooming meeting the new school spaces that replace conventional classes (Hidayat, 2021).

The impact of the Covid-19 pandemic in the education sector is felt in the East Java region, especially Sumenep, which is actually the red zone (red zone). Learning previously carried out face to face, to be turned into learning in the 
network (online) during a pandemic covid-19. Learning in the new normal era can be carried out online (in network), offline (outside the network) or a combination of the two which is better known as blanded learning (Dwiyogo, 2018). Several learning methods can be alternative, namely the Numberd Heads Together (NHT) (Ilahi et al., 2020), multimedia-based learning model, hybrid-learning, and blended learning.

In Sumenep, the area consists of urban, rural and island with a variety of infrastructure development and equitable distribution of diverse technologies, as well as different social and economic conditions make learning implemented in some areas tend to be different. In urban areas, it is possible to carry out online learning because of adequate access to information technology, the socioeconomic conditions that are on average middle and above allow learning to be carried out online at both the primary and secondary school levels. By contrast, in rural areas and islands with access to information technology are very limited, the flow of electricity only 12 hours a day, and socioeconomic conditions of the average lower middle does not allow the implementation of the study carried out online, can be performed offline (outside the network) by way of teachers to the homes of students one by one or the students gathered in a place such as village halls that allow teachers can implement effective learning but still comply with health protocols such as wearing masks, keep their distance, wash hands before and after study, are prohibited from borrowing stationery and books lesson.

The implementation of learning both online and offline in urban, rural and island areas is not without obstacles. Especially for physical education (PE) teachers, whose learning is more dominant in the psychomotor aspects which are more effectively implemented face-to-face. The teacher can provide an example directly and students can practice the movements and be directly evaluated by the teacher. Supervision and control of complex movements by the teacher are also of particular concern in providing online material with complex movements such as front roll, back roll, wax stance, kayang stance. Teachers must consider the availability of facilities and infrastructure in the student environment so that 


\section{OLATRAGA

online learning is more effective. Teachers should plan learning appropriately, provide innovation and the right media so that students interested in the material given by the teacher. Teachers must be creative in implementing learning online such as the use of tools in the house that could be used as a tool to support learning, simple gestures that enable the student to perform these movements, video tutorials interesting (Batubara \& Batubara, 2020; Widyalaksono et al., 2020).

$\mathrm{PE}$ teachers are required to make the virtual learning atmosphere enjoyable by doing physical activities. Learning through good physical activity will provide enjoyment for students (Mashuri, 2019). In addition to the PE teacher should also be able to develop cognition and practice the noble values that are manifested in the lifestyle of learners (Mashuri et al., 2019). So that through the use of media and applications that are in accordance with learning needs, it is hoped that they will be able to realize the essence of PE.

The use of appropriate media and applications will also make it easier for students and teachers to communicate. Applications are often used sports and physical education teachers in teaching online health was partly whatsapp, youtube, google meet, google form, zoom, facebook (Yulianto, 2020). Learning oriented physical activities such as sports, games big ball, activity rhythmic, athletic and traditional games are very useful especially to improve the immune system of students, increase physical literacy among students (Gustian, 2020) so that the need for movement into their daily needs and students are used to doing physical activity every day like a bike to school, running and walking.

The covid-19 pandemic provides opportunities for PE teachers to provide online learning. Online learning during the Covid-19 pandemic had an impact on PE teachers. so there needs to be an in-depth analysis of the impact of online learning during the Covid-19 pandemic for PE teachers. 


\section{METHOD}

This study uses a qualitative approach with survey techniques, where the data collection tool uses a questionnaire containing a number of statements that must be answered by respondents (Maksum, 2018). Data collection techniques in this study by sending questionnaires to respondents via google form. The research object was all primary and secondary PE teachers in Sumenep Regency. The research instrument was developed according to the conditions and characteristics of the students. The questionnaire development was validated by 3 experts in the field of online learning, including PE academics, PE practitioners, and learning technology expertsSo that the description of the questionnaire in this study is as follows.

Table 1. The Overview of the Questionnaire on the Impact of Online Learning

\begin{tabular}{|c|c|c|}
\hline Variable & Indicators & Question Items \\
\hline Learning Methods & $\begin{array}{l}\text { Strategy, Media, Evaluation, Learning } \\
\text { Materials }\end{array}$ & $1,2,5,7$ \\
\hline Constraints & Learning Barriers & 3 \\
\hline Solution & Problem Solving & 4 \\
\hline Impact & Learning Outcomes, Knowledge, Attitudes & $6,8,9$ \\
\hline Expectation & Prospect & 10 \\
\hline
\end{tabular}

\section{RESULT AND DISCUSSION}

The results of the questionnaire in this study are presented in several ways that are discussed to focus more on the results of the research, then the discussion is in accordance with the questionnaire distributed to the respondents as follows.

PE learning materials delivered by PE teachers during online learning during the Covid-19 pandemic are in accordance with the existing curriculum. The PE material provided by the teacher in accordance with the basic competencies to be achieved though the implementation of online learning conducted.

PE learning strategies and innovations related to online learning by preparing interesting teaching materials, media that inspire students, making practical learning videos, and an online evaluation system. Based on the research 


\section{OLAARAAA}

results, PE teachers have the creativity to prepare learning materials properly and learning materials can be understood by students, considering that online learning has a high enough level of anxiety. This concurs with Oktawirawan (2020) who said that triggers for student anxiety in online learning include students having difficulty understanding the material. Therefore, PE teachers prepare learning materials before online learning such as reading the material to be delivered, making power points, preparing e-learning and preparing the needs of learning materials.

Some other subjects that give assignments to students. this makes students become stressed so students prefer to ignore things related to school. The stress experienced by students should be overcome with physical activities that are usually carried out in physical education learning. based on research conducted by Asri \& Octaviana (2021), that there is a significant relationship between exercise habits and stress. The role of physical education teachers has a strategic role to improve students' mental health.

PE teachers use learning media as a simple learning aid. The PE learning media in question is a learning aid that is easily found at home and is used in the PE learning process which is dominant in the motoric aspect so that students have no difficulty in carrying out the motion tasks ordered by the teacher. Other media such as electronic media in the form of mobile phones that support the use of several applications used by PE teachers in carrying out the learning process online such as the WhatsApp application, google meet, zoom, edmodo and other applications that support the implementation of the learning process effectively. The use of these applications really helps teachers and students in the implementation of the learning process online (Oktaviani et al., 2020). The use of the google classroom application has also proven effective in implementing online learning (Nurani et al., 2020).

Evaluation of PE learning in the online learning process by PE teachers in Sumenep District emphasizes cognitive, affective and psychomotor abilities. Evaluation of students' cognitive abilities on the material that the PE teacher has 
given uses a quiz that contains questions that are sent via the WhatsApp application. Evaluating affective abilities, PE teachers assess students' discipline through collecting assignments on time. Evaluation of the teacher's psychomotor abilities instructs students to record motion assignments given by the teacher and send a video of the assignment via the WhatsApp application.

The findings in this study are the obstacles experienced by teachers and students during physical education learning. Students in the village, their main obstacle is not having a smartphone. The second obstacle is the geographical location of the students which affects the internet network. So that students have to find a strong network point or use the wifi available in several village halls. The third obstacle is the limited internet quota. Although the government provides internet quota assistance, all subjects taught in schools use online learning, so the internet quota runs out faster. The fourth obstacle is the response of students in online learning. Delivering information to students through applications, of course, has different speeds. For students who are in areas with fast internet access speeds, information in the form of learning materials will arrive quickly. For students in areas with inadequate internet access speeds, this will be a separate obstacle related to the delivery of learning material by the teacher, as well as student responses to assignments given by the teacher.

The results showed that the obstacles experienced by teachers during online learning were learning applications, internet networks and devices, learning management, assessment and supervision (Rigianti, 2020). Elianur (2020) in his research stated that the majority of teachers said online learning was ineffective because of the lack of explanations for learning by teachers to students. The student or the parents do not have a phone that supports online learning, lack of interaction between teachers and students, inadequate internet network and internet charges are quite expensive.

The solution offered by physical education teachers to the obstacles faced by both teachers and students so that learning is more effective is that teachers meet students directly (offline) with the door to door method. By using this 
method, the teacher can provide learning material to students who have limitations both in terms of economics and knowledge of technology. The teacher can also provide learning materials by gathering students in a place such as the village hall and adhere to health protocols by maintaining distance, washing hands, wearing masks, and not borrowing stationery. In this case the village government facilitates students who are constrained in implementing online learning by providing a place and access to the internet network for its residents.

Online learning during the COVID-19 pandemic has had several impacts on teachers, both positive and negative impacts. The positive impact of implementing online learning is that teachers are required to have digital literacy skills, meaning that teachers must be able to obtain, understand, and use information from various sources in digital form. Teachers are required to be more creative and innovative in the learning process through the use of technology, such as preparing materials, making video tutorials, preparing learning media, using applications in learning and an efficient evaluation system. The negative impact of implementing online PE learning is that the provision of material is only theoretical, cannot use physical activities such as face-to-face learning, and teacher supervision of students in practical learning is not optimal so that teachers are only limited to providing practical material that is safe for students at home. Physical activities suggested by the Physical Education teacher in implementing this online learning are light activities such as jogging, walking, rhythmic exercise, aerobic exercise or other activities using media or tools at home.

Educational impact of implemented online learning is that the learning process is less effective because of the constraints experienced by teachers, students and parents. Decreased fitness and increased obesity because the activities carried out by students cannot be directly supervised and controlled by the teacher, and basic competencies are not achieved due to the ineffective teaching and learning process.

Thus, online learning requires strengthening cooperation between schools, teachers, students and parents, because the role of these three elements is very 
important in supporting the effectiveness of online learning (Rahman, 2020). The expectations of PE teachers regarding the implementation of online learning are training on the use of the Learning Management System (LMS) in the implementation of online PE learning. The big hope is that the Covid-19 pandemic will end soon so that face-to-face learning can be carried out in schools.

\section{CONCLUSION}

Based on the results of research and in-depth analysis, it can be concluded that the impact of PE learning on PE teachers during the Covid-19 pandemic, namely teachers are required to improve and develop digital literacy, PE teachers must have strategies and innovations in PE learning so that students stay motivated to maintain fitness. PE teachers must choose the right media so that the implementation of learning is more interesting. The big hope of PE teachers during the Covid-19 pandemic is the realization of good cooperation between teachers, students, parents, and schools to create a conducive learning atmosphere.

\section{REFERENCES}

Asri, N., \& Lely Octaviana, E. S. (2021). Aktivitas Olahraga Di Masa Pandemi COVID-19 Terhadap Tingkat Stres Mahasiswa Pendidikan Olahraga Universitas Islam Kalimantan Muhammad Arsyad Al Banjari Banjarmasin. Halaman Olahraga Nusantara (Jurnal Ilmu Keolahragaan). https://doi.org/10.31851/hon.v4i1.5213

Batubara, H. H., \& Batubara, D. S. (2020). Penggunaan Video Tutorial Untuk Mendukung Pembelajaran Daring Di Masa Pandemi Virus Corona. Muallimuna: Jurnal Madrasah Ibtidaiyah, 5(2), 21. https://doi.org/10.31602/muallimuna.v5i2.2950

Dunton, G. F., Do, B., \& Wang, S. D. (2020). Early effects of the COVID-19 pandemic on physical activity and sedentary behavior in children living in the U.S. BMC Public Health, 20(1), 1-13. https://doi.org/10.1186/s12889020-09429-3

Dwiyogo, W. D. (2018). Pembelajaran Berbasis Blended Learning. PT. Raja Grafindo Persada. 


\section{Accredited}

SINTA 3

\section{Elianur, C. (2020). Pilihan Media Pembelajaran Daring Oleh Guru Pai Di Bengkulu Tengah. Jurnal As-Salam, 4(1), 37-45.} https://doi.org/10.37249/as-salam.v4i1.142

Gustian, U. (2020). Permainan tradisional: suatu pendekatan dalam mengembangkan physical literacy siswa sekolah dasar Traditional games : an approach to developing students physical literacy in elementary school Uray Gustian PENDAHULUAN Era abad ke-21 telah terjadi perkemba. Jurnal SPORTIF: Jurnal Penelitian Pembelajaran, 6(1), 199-215.

Hidayat, O. R. (2021). Arah Pendidikan Islam Di Era New Normal. Jurnal Fakultas Ilmu Keislaman, 2(1), 6.

Ilahi, B. R., Syafrial, \& Hiasa, F. (2020). Implementasi Model Pembelajaran Kooperatif Tipe Numbered Heads Together pada Mahasiswa Pendidikan Jasmani Universitas Bengkulu. Halaman Olahraga Nusantara (Jurnal Ilmu Keolahragaan), 3(2), 207-213. https://doi.org/10.31851/hon.v3i2.4858

Jatira, Y., \& Neviyarni. (2021). Fenomena Stress dan Pembiasaan Belajar Daring Dimasa Pandemi Covid-19. Edukatif: Jurnal Ilmu Pendidikan, 3(1), 35-43.

Maksum, A. (2018). Metodologi Penelitian dalam Olahraga (Kedua). Unesa University Press.

Mashuri, H. (2019). Analisis Tingkat Kenikmatan Beraktifitas Fisik Peserta Didik Pendidikan Jasmani Sekolah Menengah Kejuruan. Jurnal Pendidikan Jasmani, Olahraga Dan Kesehatan, 3(1), 55-70. https://doi.org/10.33503/jp.jok.v3i1.602

Mashuri, H. (2020). Simple Trick: Tri Dharma Perguruan Tinggi Dosen Pendidikan Jasmani Selama Pandemi Covid-19. In W. D. Dwiyogo (Ed.), Pembelajaran Di Masa Covid-19 - Work From Home (pp. 65-71). Wineka Media.

Mashuri, H., Puspitasari, I. C., \& Abadi, S. M. (2019). Pendidikan Jasmani dan Olahraga: Sebuah Pandangan Filosofi. Prosiding Seminar Pendidikan Dan Pembelajaran, 3, 383-390.

Nurani, N. I., Uswatun, D. A., \& Maula, L. H. (2020). Analisis Proses Pembelajaran Matematika Berbasis Daring Menggunakan Aplikasi Google Classroom Pada Masa Pandemi Covid-19. Jurnal PGSD, 6(1), 50-56. https://doi.org/10.32534/jps.v6i1.1151

Okilanda, A., Dlis, F., Humaid, H., Putra, D. D., Arisman, A., \& Muslimin, M. (2021). Defense Warm-Up Exercise Material for 13-Age Athlete Using Video Technology in Covid-19 Era. International Journal of Human 
HALAMAN Tendral A. Yani Street Lorong Gotong Royong 9/10 Ulu OLATRAGA

Movement and Sports Sciences, 9(4), 629-634. https://doi.org/10.13189/saj.2021.090404

Oktaviani, I., Waspada, I., \& Budiwati, N. (2020). Penerapan Media Pembelajaran E-Learning Berbasis Edmodo Pada Pembelajaran Daring Saat Pandemi Covid-19 (Ditinjau Dari Persepsi Siswa). Jurnal IKA PGSD (Ikatan Alumni PGSD) UNARS, 8(1), 68. https://doi.org/10.36841/pgsdunars.v8i1.584

Oktawirawan, D. H. (2020). Faktor Pemicu Kecemasan Siswa dalam Melakukan Pembelajaran Daring di Masa Pandemi Covid-19. Jurnal Ilmiah Universitas Batanghari Jambi, 20(2), 541. https://doi.org/10.33087/jiubj.v20i2.932

Rahman, T. (2020). Peran Strategis Orang Tua dan Teknologi dalam Pembelajaran Pendidikan Jasmani Olahraga dan Kesehatan secara Daring di Era New Normal. In H. N. Muhammad (Ed.), Strategi, Proses, Evaluasi dan Model Pembelajaran (pp. 51-55). Unesa University Press.

Rigianti, H. (2020). Kendala Pembelajaran Daring Guru Sekolah Dasar di Kabupaten Banjarnegara. Elementary School: Jurnal Pendidikan Dan Pembelajaran Ke-SD-An, 7(2), 297-302.

Widyalaksono, P., Mashuri, H., \& Lusianti, S. (2020). Penerapan Media Audio Visual untuk Meningkatkan Hasil Belajar Gerak Dasar Pola Langkah Pencak Silat Sekolah Dasar. Gelanggang Pendidikan Jasmani Indonesia, 4(1), 8-17.

Xiang, M., Zhang, Z., \& Kuwahara, K. (2020). Impact of COVID-19 pandemic on children and adolescents' lifestyle behavior larger than expected. Progress in Cardiovascular Diseases, 63(4), 531-532. https://doi.org/10.1016/j.pcad.2020.04.013

Yulianto, D. (2020). Pengaruh Pembelajaran Daring Pengguna Platform Digital Terhadap Pemecahan Masalah Matematis Dan Sikap Kritis Siswa Di Ma Daar El Qolam. Symmetry: Pasundan Journal of Research in Mathematics Learning and Education, 5(5), 107-128. https://doi.org/10.23969/symmetry.v5i1.2790 